\title{
Medical management of ectopic pregnancy
}

\section{Tseten Zangmu Bhutia1, Zigmee Dorjee Tamang ${ }^{2 *}$, Goutam Giri ${ }^{1}$}

\begin{abstract}
${ }^{1}$ Department of Obstetrics and Gynecology, Ramkrishna Mission Seva Pratisthan, Kolkata, West Bengal, India
${ }^{2}$ Department of Obstetrics and Gynecology, Sikkim Manipal Institute of Medical Sciences, Sikkim, India
\end{abstract}

Received: 11 July 2020

Accepted: 07 August 2020

\section{*Correspondence:}

Dr. Zigmee Dorjee Tamang,

E-mail: tamangzigmee@gmail.com

Copyright: (C) the author(s), publisher and licensee Medip Academy. This is an open-access article distributed under the terms of the Creative Commons Attribution Non-Commercial License, which permits unrestricted non-commercial use, distribution, and reproduction in any medium, provided the original work is properly cited.

\section{ABSTRACT}

Background: Ectopic pregnancy is a commonest cause of maternal morbidity and mortality in the first trimester of pregnancy. Clinical presentation of ectopic pregnancy has changed from life threatening disease to a more benign condition for which nonsurgical treatment options are available with methotrexate administered systemically or locally. The study was done to evaluate the outcome of medical management of ectopic pregnancy with single regimen methotrexate.

Methods: A cohort study was conducted over 18 months on 60 unruptured ectopic pregnancies who were treated with methotrexate injection.

Results: Out of 60 unruptured ectopic pregnancies, $53(88.3 \%)$ were successfully treated with methotrexate. Failure rate was $11.7 \%(7 / 60)$ patients who underwent laparotomy. Success of medical treatment was dependent on pretreatment $\beta$-hCG $(\leq 4102.5 \mathrm{mIU} / \mathrm{mL})$, period of gestation $(\leq 5$ weeks), size of gestational sac $(\leq 3 \mathrm{~cm})$ above which the failure rate increases. No correlation was seen between fall of $\beta$-hCG from day 4 to 7 and the success rate. Mean time to resolution of $\beta$-hCG seen was $4.3 \pm 1.25$ weeks. Mean duration of hospital stay was $8.85 \pm 1.603$ days. Single dose regimen of methotrexate was given to all patients and only $1 / 60$ patients required second dose of methotrexate for suboptimal decrease of $\beta$-hCG.

Conclusions: The result showed that pretreatment $\beta$-hCG level and period of gestation were good predictors for success of medical treatment.

Keywords: Ectopic pregnancy, Methotrexate, $\beta$-hCG

\section{INTRODUCTION}

Ectopic pregnancy occurs when fertilized ovum gets implanted in tissue other that the endometrium. It is a common life-threatening emergency in the developing world and the commonest cause of maternal morbidity and mortality in the first trimester of pregnancy. ${ }^{1}$

According to centre for disease control and prevention, ectopic pregnancy accounts for approximately $2 \%$ of all reported pregnancy. ${ }^{2}$ Fallopian tube being the most common site of ectopic implantation, accounting for more than ninety percent. ${ }^{3}$
Risk factors include prior ectopic pregnancy to be the commonest, followed by prior tubal surgery, pelvic inflammatory disease (PID), smoking, prior medical or surgical abortion, infertility and its treatment, prior intra uterine contraceptive device (IUCD) use in case of failure. ${ }^{4}$ Currently early high suspicion, serial hormonal assays and transvaginal sonography (TVS) facilitates the early diagnosis and treatment of ectopic pregnancy before it ruptures. This has resulted in a dramatic decline in mortality rate. ${ }^{5}$

The management for an ectopic pregnancy includes surgery, medical or rarely expectant management. Over 
the time the clinical presentation of ectopic has changed from life threatening disease to a more benign condition for which nonsurgical treatment options are available, with methotrexate (MTX) being the most commonly given drug for a medical management of ectopic pregnancy. It is a folic acid analogue that inhibits dihydrofolate reductase and thereby prevents synthesis of DNA.

Multiple dose regimen which was traditionally used has now been replaced by single dose regimen protocol which were easier with better patient compliance, less expensive, requiring less monitoring and treatment results and prospects for future fertility were comparable. ${ }^{6}$ The overall effectiveness of methotrexate therapy ranges from 78-96\%. ${ }^{7}$ High pre-treatment serum $\beta$-human chorionic gonadotropin (hCG) levels has shown to be the most important predictor for medical treatment failure, although which treatment modality is appropriate for specific range of pre-treatment serum $\beta$-hCG level still remains unclear. ${ }^{10}$

The decision for medical or surgical management of ectopic pregnancy should be guided by the initial clinical, laboratory and radiological data using specific criteria as well as patient informed choice based on discussion of benefits and risk of each approach.

The purpose of this study is to evaluate the outcome of medical management of ectopic pregnancy using a single dose regime of methotrexate.

\section{METHODS}

Prospective cohort study conducted in the department of Obstetrics and gynecology RIMS, Imphal from $1^{\text {st }}$ September 2016 to $28^{\text {th }}$ February 2018. Sixty patients with confirmed diagnosis of unruptured ectopic pregnancy who were hemodynamically stable and fulfilling the inclusion and exclusion criteria were recruited for the study.

\section{Inclusion criteria}

Patients included with hemodynamically stable, adnexal mass $<4 \mathrm{~cm}, \beta$-hCG $<5000 \mathrm{mIU} / \mathrm{mL}$, no fetal cardiac activity on USG, hemoperitoneum $<100 \mathrm{ml}$ were included in this study.

\section{Exclusion criteria}

Patients with sensitivity to methotrexate, liver, hematological and renal impairment, presence of fetal activity, breast feeding, inability to participate in followup were excluded from the study.

After obtaining informed written consent, a detailed history was taken from the patients i.e., age, parity, last menstrual period, period of amenorrhoea, lower abdominal pain, bleeding per vagina and past history to rule out risk factors i.e., previous ectopic pregnancy, PID, infertility, contraception, abdomino-pelvic surgery, abortions. After detailed history patient were examined thoroughly including abdomino-pelvic examination for tenderness, guarding, rigidity, distension, cervical excitation.

Investigations such as complete hemogram, blood grouping, liver function test, kidney function test, serum $\beta$-hCG were done. All patients were administered a single dose of $50 \mathrm{mg} / \mathrm{m}^{2}$ MTX on day 1 and measured $\beta$-hCG level on day 4 and 7 . If the decrease in $\beta$-hCG level was $>15 \%$ we considered treatment successful and followed weekly until it reaches non pregnant level. If the decrease in $\beta$-hCG level on day 4 and 7 was $<15 \%$, second dose of methotrexate was administered. If $\beta-\mathrm{hCG}$ level did not decrease after two doses, authors considered surgical management.

\section{Statistical analysis}

All details were entered in a pre-designed performa and analysed using SPSS 21 IBM. Descriptive statistics like mean, percentage and standard deviation were used. For differential statistics, Chi square, Fisher's exact test and independent $\mathrm{t}$-test were utilized and $\mathrm{p}$-value $<0.05$ was taken significant.

\section{RESULTS}

After screening for inclusion and exclusion criteria 60 unruptured ectopic pregnancy who came during the study period were included.

\section{Table 1: Distribution of cases according to outcome} of treatment.

\begin{tabular}{|lll|}
\hline Outcome & No. of cases & Percentage \\
\hline Success & 53 & 88.3 \\
\hline Failure & 7 & 11.7 \\
\hline Total & 60 & 100.0 \\
\hline
\end{tabular}

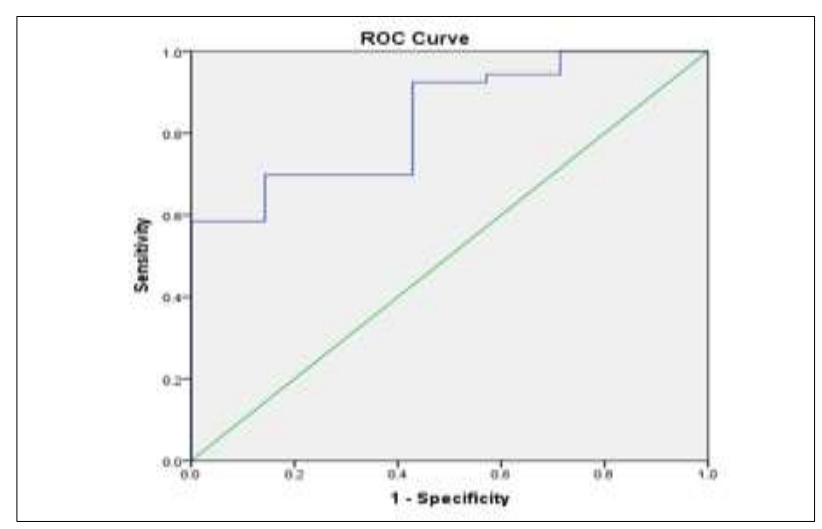

Figure 1: Receiver operating characteristic (ROC) curves for initial $\beta$-hCG concentration on successful outcome. $\beta$-hCG area under curve $=0.836$, $\mathrm{SE}=0.069, \mathrm{p}=0.04$. 
The cut off hCG value which determined the failure of MTX treatment with sensitivity of $92.5 \%$ and specificity of $57.1 \%$ in ROC curve analysis was found to be $>4102.50 \mathrm{mIU} / \mathrm{mL}$.

Table 2: Correlation of level of $\beta$-hCG on day 1 with treatment outcome.

\begin{tabular}{|llll|}
\hline Level of $\boldsymbol{\beta}-\mathrm{hCG}$ & $\begin{array}{l}\text { Outcome } \\
\text { Success } \\
\mathbf{n}(\boldsymbol{\%})\end{array}$ & $\begin{array}{l}\text { Failure } \\
\mathbf{n}(\boldsymbol{\%})\end{array}$ & $\begin{array}{l}\text { P } \\
\text { value* }\end{array}$ \\
\hline $\mathbf{4} \mathbf{4 1 0 2 . 5}$ & $49(94.2)$ & $3(5.8)$ & \multirow{2}{*}{0.004} \\
\hline $\mathbf{> 4 1 0 2 . 5}$ & $4(50)$ & $4(50)$ & \\
\hline
\end{tabular}

*Fisher's exact test.

Table 3: Correlation of fall in $\beta$-hCG level on day 4 and 7 with treatment outcome.

\begin{tabular}{|l|ll|l|}
\hline \% fall in $\boldsymbol{\beta}$-hCG & $\begin{array}{l}\text { Outcome } \\
\text { Success } \\
\mathbf{n}(\boldsymbol{\%})\end{array}$ & $\begin{array}{l}\text { Failure } \\
\mathbf{n}(\boldsymbol{\%})\end{array}$ & $\begin{array}{l}\text { P } \\
\text { value* }\end{array}$ \\
\cline { 1 - 3 } $\mathbf{1 \mathbf { 1 5 }}$ & $0(0)$ & $1(100)$ & 0.117 \\
\hline $\mathbf{1 5}$ & $53(89.3)$ & $6(10.2)$ & \\
\hline
\end{tabular}

*Fisher's exact test.

Maximum number of patients (59/60) had fall of $\beta$-hCG value more than equal to $15 \%$ between day 4 and day 7 . Inspite of fall of $\beta$-hCG between day 4 and day 7 , there was a failure rate of $10.2 \%(6 / 60)$ cases. There was no significant relation between fall of $\beta$-hCG between day 4 to day 7 and treatment outcome $(p=0.117)$.

Table 4: Correlation of size of ectopic with treatment outcome.

\begin{tabular}{|llll|}
\hline Size of ectopic & $\begin{array}{l}\text { Outcome } \\
\text { Success } \\
\mathbf{n}(\boldsymbol{\%})\end{array}$ & $\begin{array}{l}\text { Failure } \\
\mathbf{n}(\boldsymbol{\%})\end{array}$ & $\begin{array}{l}\text { P } \\
\text { value* }\end{array}$ \\
\hline$\leq 3 \mathbf{~ c m}$ & $26(96.3)$ & $1(3.7)$ & \multirow{2}{*}{0.116} \\
\hline $\mathbf{4} \mathbf{~ c m}$ & $27(81.8)$ & $6(18.2)$ & \\
\hline
\end{tabular}

*Fisher's exact test.

Failure rate was found to be $3.7 \%$ when size of ectopic pregnancy was less than equal to $3 \mathrm{~cm}$ and above its failure rate was $18.2 \%$. Here, $\mathrm{p}$ value is 0.116 . Therefore, the association was found to be insignificant.

Table 5: Correlation of period of amenorrhea with treatment outcome.

\begin{tabular}{|llll|}
\hline $\begin{array}{l}\text { Period of } \\
\text { amenorrhoea (in } \\
\text { weeks) }\end{array}$ & $\begin{array}{l}\text { Outcome } \\
\text { Success } \\
\mathbf{n}(\boldsymbol{\%})\end{array}$ & $\begin{array}{l}\text { Failure } \\
\mathbf{n}(\boldsymbol{\%})\end{array}$ & $\begin{array}{l}\text { P } \\
\text { value* }\end{array}$ \\
\hline $\mathbf{5}$ & $23(100)$ & $0(0)$ & 0.037 \\
\hline$>\mathbf{5}$ & $30(81.1)$ & $7(18.9)$ & \\
\hline
\end{tabular}

*Fisher's exact test.

A total $9(15 \%)$ out of 60 cases were admitted again despite of fall in hCG level from day 4 to day 7 (Table 7).
Table 6: Distribution of cases according to reason for failure.

\begin{tabular}{|lll|}
\hline Reason for failure & No. of cases & Percentage \\
\hline $\begin{array}{l}\text { Haemodynamic } \\
\text { unstability }\end{array}$ & 3 & 42.9 \\
\hline Severe pain & 3 & 42.9 \\
\hline Persistent pain abdomen & 1 & 14.2 \\
\hline Total & 7 & 100 \\
\hline
\end{tabular}

Table 7: Distribution of cases according to need for readmission.

\begin{tabular}{|lll|}
\hline Readmission & $\begin{array}{l}\text { No. of } \\
\text { patients }\end{array}$ & Percentage \\
\hline No & 51 & 85.0 \\
\hline Yes & 9 & 15.0 \\
\hline Total & 60 & 100.0 \\
\hline
\end{tabular}

Table 8: Distribution of cases according to reason for readmission.

\begin{tabular}{|lll|}
\hline $\begin{array}{l}\text { Reason for } \\
\text { readmission }\end{array}$ & No. of cases & Percentage \\
\hline Moderate pain & 5 & 55.6 \\
\hline Severe pain & 3 & 33.3 \\
\hline $\begin{array}{l}\text { Sub-optimal decrease } \\
\text { in hCG }\end{array}$ & 1 & 11.1 \\
\hline
\end{tabular}

Table 9: Distribution of cases according to management after readmission.

\begin{tabular}{|lll|}
\hline Management & No. of cases & Percentage \\
\hline Conservative & 6 & 66.7 \\
\hline Surgery & 3 & 33.3 \\
\hline Total & 9 & 100.0 \\
\hline
\end{tabular}

Table 10: Distribution of cases according to resolution time of $\beta$-hCG.

\begin{tabular}{|lll|}
\hline $\begin{array}{l}\text { Time to resolution } \\
\text { (in weeks) }\end{array}$ & No. of cases & Percentage \\
\hline $\mathbf{3 - 4}$ & 18 & 33.9 \\
\hline $\mathbf{4 - 6}$ & 32 & 60.4 \\
\hline $\mathbf{> 6}$ & 3 & 5.7 \\
\hline Total & 53 & 100.0 \\
\hline Mean \pm SD & & $4.36 \pm 1.25$ \\
\hline
\end{tabular}

Maximum number of cases $60.4 \%$ had a resolution time of 4-6 weeks, followed by $33.9 \%$ of cases with resolution time of 3-4 weeks and $5.7 \%$ of cases with resolution time more than 6 weeks. Mean time to resolution of $\beta$-hCG was $4.36 \pm 1.25$ weeks.

\section{DISCUSSION}

One of the known factors associated with MTX treatment success is the pretreatment $\beta$-hCG levels, but threshold 
reported in the literature vary from $1000 \mathrm{mIU} / \mathrm{mL}$ to as much as $5000 \mathrm{mIU} / \mathrm{mL}$. In the present study, we found that cut off $\beta$-hCG value by using ROC curve to predict MTX failure was $4102.50 \mathrm{mIU} / \mathrm{mL}$ with $92.5 \%$ sensitivity and $57.1 \%$ specificity. In patients with $\beta$-hCG level $>4102 \mathrm{mIU} / \mathrm{mL}$, the failure rate was $50 \%$ whereas in patients with lower $\beta$-hCG levels, failure rate was $5.8 \%$. Hence positive correlation was seen between $\beta$ hCG and success rate. The study conducted by Vaswani et al revealed the cut off $\beta$-hCG level for success as 6000 $\mathrm{mIU} / \mathrm{mL}$ and to be good predictors for success rate. ${ }^{8}$ In the study conducted by Menon $\mathrm{S}$ et al, a cut off of pretreatment $\beta$-hCG value was $5000 \mathrm{mIU} / \mathrm{mL}$ and substantial increase in failure was noted when $\beta$-hCG value was $>5000 \mathrm{mIU} / \mathrm{mL}^{9}{ }^{9}$

In study, patients with ectopic size $\leq 3 \mathrm{~cm}$ had $96.3 \%$ success rate and with $4 \mathrm{~cm}$ size $81.1 \%$ success rate. No significant relationship was found between ectopic size and treatment success. Vaswani et al in their study showed size $\leq 3 \mathrm{~cm}$ to be a good predictor of success. ${ }^{8}$

In the present study, patients with period of gestation $\leq 5$ weeks have $100 \%$ success rate and above the level have $81.1 \%$ success. The correlation between period of gestation and success rate was significant. Similar study was conducted by Vaswani et al where period of gestation $<6$ weeks to be a good predictor for success of medical management of ectopic pregnancy. ${ }^{8}$

The fall of $\beta$-hCG value $>15 \%$ from day 4 to day 7 was $87.9 \%$. There was no correlation with fall of $\beta$-hCG value from day 4 to day 7 with the success rate. This can be due to unequal distribution of patients for fall of $\beta$-hCG value.

In the present study, $9(15 \%)$ patients were readmitted after successful decrease of $\beta$-hCG from day 4 to day 7 . Out of which 3 patients underwent laparotomy for severe pain and termed as treatment failure, 5 readmitted patients were managed conservatively for moderate pain and one patient was given second dose of methotrexate and was successful.

Mean time to resolution of $\beta$-hCG seen in my study was $4.3 \pm 1.25$ weeks which was similar to time to resolution shown by Lee et al which was $27.4 \pm 11$ days. ${ }^{10}$ Shah et al in their study stated the time to resolution was 32 days. ${ }^{11}$

Success rate of medical management with single dose methotrexate for ectopic pregnancy in my study was $88.3 \%$ with no side effects. It was comparable with studies conducted by Shah et al where success rate was $85 \%$ and Krik et al where success rate was $91 \% .^{11,12}$

Failure rate was $(11.7 \%) 7 / 60$ patients. Among which 3 patients $(42.9 \%)$ had hemodynamic unstability, 1 patient (14.2\%) had persistent pain abdomen and $3(42.9 \%)$ of them were readmitted for severe pain abdomen after successful decrease of hCG from day 4 to day 7 . One case of cervical pregnancy with hemodynamically unstability underwent hysterectomy. Rest 6 patients underwent laparotomy out of which 5 had ruptured ectopic pregnancy.

\section{CONCLUSION}

Treatment of an ectopic pregnancy with methotrexate is safe and effective in carefully selected cases. Although methotrexate treatment is beneficial in that it allows one to avoid surgery in a patient, there are certain disadvantages. Medical treatment requires extended follow-up of patients, which can be cumbersome and difficult at times. The need to follow patients clinically until the serum $\beta$-hCG is undetectable requires multiple visits, which takes valuable time of both patient and clinician. It is appropriate for clinicians to select suitable candidates for treatment of ectopic pregnancy with methotrexate. It is imperative to confirm diagnosis to avoid unnecessary administration of a chemotherapy, such as in a completed miscarriage or early intrauterine pregnancy, that can have severe consequences for both mother and fetus. There is usually no indication that methotrexate has to be administered at the first presentation of the patient, especially if she is clinically stable. If a woman is not stable or is in significant pain, she is not a candidate for medical management. Followup hCG or ultrasound can often avoid unnecessary or contraindicated administration of methotrexate. Moreover, patients should have appropriate counselling, willingness for follow-up and no absolute contraindications to methotrexate treatment. The choice between two acceptable treatments, medicine or surgery, should be an informed, not reflective decision.

\section{Funding: No funding sources}

Conflict of interest: None declared

Ethical approval: The study was approved by the Institutional Ethics Committee

\section{REFERENCES}

1. Mahboob U, Mazhar SB. Management of ectopic pregnancy: a two-year study. J Ayub Med Coll Abbotlabad. 2006;18(4):34-7.

2. Centers for disease control and prevention (CDC). Ectopic pregnancy: United States, 1990-1992. MMWR Morb Mortal Wkly Rep. 1995;44(3):46-8.

3. Bouyer J, Coste J, Fernandez H, Pouly JL, Job-Spira N. Sites of ectopic pregnancy: a 10 year populationbased study of 1800 cases. Hum Reprod. 2002;17(12):3224-30.

4. Tay JI, Moore J, Walker JJ. Ectopic pregnancy. West J Med. 2000;17(2):131-4.

5. Berg CJ, Chang J, Collaghan WM, Whitehead SJ. Pregnancy related mortality in the United States, 1991-1997. Obstet Gynecol. 2003;101(2):289-96.

6. Barnhart KT, Gosman G, Ashby R, Sammel M. The medical management of ectopic pregnancy: a metaanalysis comparing single dose and multidose regimens. Obstet Gynecol. 2003;101(4):778-84. 
7. Pisarska MD, Carson SA, Buster JE. Ectopic pregnancy. Lancet. 1998;351(9109):1115-20.

8. Vaswani PR. Predictors of success of medical management of ectopic pregnancy in a tertiary care hospital in United Arab Emirates. J Clin Diagn Res. 2001;8(8):4-8

9. Menon S, Colins J, Barnhart KT. Establishing a human chorionic gonadotropin cut off to guide methotrexate treatment of ectopic pregnancy: a systemic review. Fertil Steril. 2007;87(3):481-4.

10. Lee Y, So C, Chan W, Lee K. Predictors of success of methotrexate in treatment of ectopic pregnancy: a new perspective. Hong Kong J Gynaecol Obstet Midwifery. 2016;16(1):73-8.
11. Shah SR, Sonara S, Patel B, Patel N. Medical management of ectopic pregnancy with methotrexate. Indian J Clin Pract. 2014;24(11):104852.

12. Krik E, Bottomley C, Bourne T. Diagnosing ectopic pregnancy and current concepts in the management of pregnancy of unknown location. Hum Reprod Update. 2014;20(2):250-61.

Cite this article as: Bhutia TZ, Tamang ZD, Giri G. Medical management of ectopic pregnancy. Int $\mathrm{J}$ Reprod Contracept Obstet Gynecol 2020;9:3809-13. 